\title{
LIETUVOS KAIMŲ SISTEMA: KONCEPCIJA, SKAIČIUS, DYDIS, TANKUMAS, IŠSIDĖSTYMAS, KITIMAS
}

\author{
Stasys Vaitekūnas, Erika Čepienè \\ Klaipédos universitetas
}

\begin{abstract}
Anotacija
Straipsnyje tiriamas gyvenviečių skaičiaus erdvinis kitimas. Diskutuojama dėl kaimo ir kaimiškumo sampratos, glaustai aptariama Lietuvos kaimų raidos istorija. Analizuojamas kaimų skaičius, jų teritorinio pasiskirstymo, tankumo ypatumai, pateikiama kaimų dydžių klasifikacija. Nustatomas kaimų artimiausios kaimynystès indeksas, nuotolis nuo pagrindinių aptarnavimo centrų, jo įtaka infrastruktūros vystymui apskrityse ir rajonuose, bandoma aptarti dabartinę kaimų vietą gyvenviečių sistemoje, jų vystymąsi ateityje.

PAGRINDINIAI ŽODŽIAI: Lietuvos kaimai, kaimiškumas, teritorinis pasiskirstymas, kaimų klasifikacija ir tipologija, kaimynystès indeksas
\end{abstract}

\begin{abstract}
The article deals with the problem of spatial and numeral changes of rural settlements. Definition of the rural settlement and rurality is discussing at the context of the settlements developing. Appropriate place is devoted to the question of the size classification and density of settlements. The research deals with the methodological problem of the index of the nearest neighbourhood of the settlements, its distance from main services centres. The question of the influence of the transport system to development of regional rural settlements is discussing as well as the future of its.

KEYWORDS: Lithuanian rural settlements, rurality, territorial distribution, classification and tipology of the villages, index rurality.
\end{abstract}

DOI: http://dx.doi.org/10.15181/tbb.v67i2.846

\section{Ivadas}

Gyvenviečių sistema svarbi tuo, kad jos kiekybinė, kokybinė bei erdvinė struktūra, jos kitimas turi įtakos valstybės ekonominiam ir socialiniam vystymuisi, raidos stabilumui. Bet kokie staigūs šios sistemos pokyčiai, ekonominiai sukrètimai ar politine valia primestos neapgalvotos reformos gali ilgam neigiamai paveikti gamybą, infrastruktūrą, visą žmonių gyvenimą. Taigi galima teigti, kad gyvenviečių sistemos ir šalies ekonominis, socialinis ir net politinis gyvenimas glaudžiai susiję. Todèl ypač svarbu būti susipažinus su realiomis ịvairių tipų gyvenviečių sistemomis, jas modeliuoti, atsižvelgiant ị esamą situaciją, numatyti ateities vystymąsi. Gyvenviečių vystymosi retrospektyva leidžia sudaryti tikslesnes ilgalaikès raidos prognozes, ypač jei jos susijusios su didelèmis sistemomis.

Svarbi šalies ar regiono gyvenviečių sistemos dalis (posistemė) yra kaimai, kurie svarbūs daugeliu požiūriu. Kaimai, jų gyventojai ne tik užtikrina didžiosios maisto dalies gamybą ir ịvairių žaliavų paruošimą pramonei, bet jie yra ir kitos, 
kai kurių tyrinètojų laikomos kokybiškai aukštesnės posistemès - miestų - ištaka. Galima teigti, kad nuo kaimų vystymosi daug priklauso visos gyvenviečių sistemos raida. Dėl to kaimų tyrimai geografijos mokslui ypač svarbūs, nes jų rezultatai padeda realiau suvokti visų geografinių-socialinių sistemų raidos ir tarpusavio sąveikos dėsningumą. Šių tyrimų rezultatai svarbūs ir ekonomistams, medicinos, švietimo bei kitų sričių specialistams, planuojantiems valstybẻs biudžeto ir ịvairių investicijų teritorinị paskirstymą, medicinos, švietimo, kultūros, kitų aptarnavimo įstaigų teritorinį ugdymą. Geografiniai kaimų, kaip dalies gyvenviečių sistemos, tyrimai yra svarbūs ir kraštotvarkos, turizmo bei poilsio specialistams, visiems, kurie susiję su kaimais bei jų aplinka, su ištekliais.

Neatsitiktinai moksliniuose tyrimuose ypač svarbu nustatyti kaimo, kaip teritorijos (lauko), ir kaimo, kaip pačios gyvenvietės bei tam tikros jos aplinkos, apibrèžimą, suvokti istorinę šio tipo gyvenviečių raidą. Taigi straipsnio tyrimo tikslas: kaimų sistemos, pagrindinių jos elementų ir parametrų tyrimas, kuris galètų tapti pagrindu ne tik būsimiems tyrimams, bet ir pateiktų rezultatus, kuriais praktiškai galètų pasinaudoti ịvairių kitų sričių specialistai.

Iš čia logiškai išplaukia ir tyrimo uždaviniai:

- kaimų sampratos apibréžimas dabartiniu visuomenès raidos laikotarpiu;

- glausta Lietuvos kaimų raidos retrospektyvos analizė;

- kaimų tipologija ir klasifikacija pagal jų dydị, teritorinị pasiskirstymą;

- kaimų skaičiaus, jų dydžių kitimo dèsningumas;

- kaimų teritorinio pasiskirstymo dèsningumas.

Tiriant kaimų raidą didžiausias dėmesys skiriamas dabartiniam nepriklausomos Lietuvos laikotarpiui, ypač laikotarpiui tarp dviejų pastarujų gyventojų ir būstų surašymų (2001 ir 2011 m.), nevengiant ir jų raidos retrospektyvos.

\section{Kaimo samprata}

Kaimo sampratos apibrèžimo klausimas iškilo dar tais laikais, kai pradejjo formuotis miestai ir atsirado privilegijuotos miestiečių klasès. Šis klausimas aktualus ir ekonominei-socialinei geografijai. Aktualumą liudija ir daugelio ịvairių šalių geografų bandymai ji gana skirtingai interpretuoti bei formuluoti.

Kaimą kai kurie tyrinètojai ir praktikai supranta kaip gyvenvietę, turinčią nedaug gyventojų, kurių dauguma dirba žemès ūkyje. Lietuvos statistikoje kaimas suprantamas kaip gyvenamoji vietovė, neturinti miesto požymių. Be to, teigiama, kad kaimo gyvenvietès tipui priskiriamas miestelis yra ne kas kita kaip kompaktiškai užstatyta vietovè, turinti nuo 500 iki 3000 žmonių. Daugelis jų dirba pramonèje, verslo, gamybos ir socialinès infrastruktūros srityse. Miesteliams priskiriamos 
ir tos gyvenvietės, kurios tradiciškai išlaikè miestelio statusą. Dèl šių kriterijų galima diskutuoti, nes visų pirma yra kaimų, kurie nelaikomi miesteliais, net jei jų gyventojų skaičius viršija kai kurių miestų gyventojų skaičių. Antra dalis miestelių gyventojų dirba būtent žemès ūkyje. Taigi galima sakyti, kad statistinis gyvenviečiu tipų apibrèžimas yra sąlygiškas, o statuso suteikimas - labiau susitarimo reikalas.

Dalis geografų teigia, kad kaimas (sodžius), kaimo gyvenvietè - tai žmonių grupe ir materialiniai ištekliai, susieti bendra teritorija, bendru gyvenimo būdu ir turintys specifinių savitarpio ryšių su gamtine aplinka, kuri daro ịtaką gamybinei veiklai (Vaitekūnas, 1989, p. 26). Kaimas apibūdinamas ir kaip ,istoriškai susiklosčiusi gyvenvietė (nuo kelių iki keliasdešimt ir daugiau sodybų, kurios dauguma gyventojų verčiasi žemès ūkiu, žvejyba, miškų ūkiu ir pan.), kuriai būdingas savitas visuomeninis ir socialinis gyvenimo būdas“ (Trakymas, Vaitekūnas, 2006, p. 133). Didesni kaimai paprastai turi ir miestiškų aptarnavimo ịstaigų: mokyklą, kultūros namus, parduotuvę, paštą, medicinos punktą. Kaimas, turintis bažnyčią, dažnai vadinamas bažnytkaimiu.

Kaimų vaizdas, kaip ir bendras kaimiškas (ruralinis) kraštovaizdis, veikiamas naujų technologinių bei ekonominių-socialinių veiksnių, laikui bėgant kito. Viduramžių kaimo branduolị sudarè keli vienas šalia kito esantys valstiečių kiemai, tarp kurių buvo glaudus funkcinis, dažniausiai infrastruktūrinis ryšys: bendriems poreikiams iškastas šulinys, per kaimą einantis kelias, apeiginių susitikimų vietos. Tai buvo būdinga kupetiniams kaimams. Kaimui priklausė aplinkinės žemès ir bendro naudojimo vieškeliai, miškai, ganyklos, vandenys.

Dabartinio kaimo apibrèžimo problematiką įžvelgia ir užsienio geografai, kurių teigimu, atskirti miesteli ar miestą nuo kaimo gana sudètinga (pvz., Goodal, 1987, p. 226). Jie akcentuoja svarbą kaimų bendruomenių, kurias sudaro žmonès, gyvenantys tame pačiame kaime, glaudžiai susiję vienas su kitu ir su gyvenamaja aplinka. Taip pat teigiama, kad „kaimo bendruomenè sudaro smulkiausią socialinę grupę, kurią susieja ir bendri kasdieniai reikalai“" (Mayhew, 1997, p. 366).

Dalis geografų teigia, kad kaimas yra gyvenamoji žmonių, užsiimančių augalų kultivavimu ir gyvulių auginimu, vieta. Žinoma lenkų geografẻ M. KielczewskaZalieska tvirtina, kad ,geografiniu požiūriu žemès ūkio gyvenvietè, kurios žmonės gyvena iš žemės naudojimo ir pasižymi specifiniu gyvenimo būdu bei darbu, yra kaimas“ (Kielczewska-Zalieska, 1974, s. 50). Jos mintis pratęsia kiti lenkų geografai. Jų nuomone, kiekviena gyvenviete, kurios dauguma gyventojų užsiima žemès ūkio darbais ir iš to pragyvena, nepaisant jų skaičiaus, yra kaimas (pvz., Szymańska, 2009, s. 62). Pagrindinis miestų ir kaimų atskirties rodiklis pirmiausia yra gyventojų profesinè struktūra, jų ryšys su žeme. Šie ekonominiai funkciniai ryšiai turi įtakos ir gyvenimo būdui, tradicijoms bei papročiams. Geografų sufor- 
muluotus apibrèžimus perėmè ir kiti su kaimais, kraštovaizdžiu susiję specialistai, nors tuos objektus jie mato iš savo pozicijų.

XXI a. akcentuojamos naujos kaimo gyventojų funkcijos: natūralaus kraštovaizdžio, istorijos ir kultūros paminklų išsaugojimas, jų aplinkos tvarkymas bei pritaikymas pažintinei švietejišskai veiklai, gamtą tausojanti įvairiapusiška ūkinè veikla, etnografinès kūrybos puoselejjimas ir jos perdavimas ateities kartoms (Rural Policy Perspectives (...), 2004, p. 196).

Europos kaimiškųjų sričių chartijoje, kuri priimta Europos Tarybos parlamentinejje asamblëjoje 1995 m., teigiama, kad kaimui būdinga vyraujanti žemès ūkio veikla, ekologinę funkciją atliekančios atviros žaliosios zonos, dekoncentruotas gyventojų ir nuosavybės (nekilnojamojo turto) objektų išdėstymas, žmonių darbu suformuotas kraštovaizdis, savita vietinè (regioninè) kultūra. Kaimai - tai tam tikros gyvenamųjų vietovių sistemos, leidžiančios žmonėms tiesiogiai bendrauti sprendžiant valdymo klausimus. Be to, chartijoje nustatytos pagrindinès kaimų funkcijos: ekonominè (žaliavos maisto produktams ir pramonei gamyba), socialinè (žmonių ryšio su natūralia aplinka išsaugojimas) ir ekologinè (racionalus gamtos išteklių naudojimas ir apsauga).

Šių laikų pasaulyje ir net Europoje galima matyti, kiek daug yra kaimu ir kaimiškumo apibrèžimų. Vienintelio nediskutuojamo kaimo apibrèžimo nèra, nes patys kaimai skirtingose valstybėse ne tik skiriasi dydžiu, bet ir pasižymi kultūros, demografinių, socialinių-ekonominių procesų, aplinkos ir kita ịvairove. Todèl šių sąvokų apibrèžimus atskirose valstybėse dažnai lemia skirtingi administraciniai ịstatymai. Pvz., Danijoje, Airijoje, Italijoje, Ispanijoje ir Švedijoje kaimai apibrèžiami pagal juose gyvenančių žmonių skaičių, o Danijoje ir Švedijoje - dar ir pagal sodybų išsidèstymo viena nuo kitos atstumą (Hoggart, Buller, Black, 1995, p. 21). Sparčios urbanizacijos procese kaimai vis dažniau patenka ị urbanizuotas zonas, kinta kaimiečių darbo pobūdis, profesinè struktūra ir gyvenimo sąlygos. Kaimuose vis labiau ịsigali miestiškas gyvenimo būdas, o pats darbas žemės ūkyje tolsta nuo tradicinio gamybos proceso.

Tyrinètojai praktiniais tikslais vis didesnị dèmesį skiria ne tik kaimų gyvenviečių, bet ir pačiai kaimiškumo sąvokai. 2010 m. Europos Komisija sutiko su nauja OECD pasiūlyta metodologija, kuri leidžia skirti kaimiškuosius, miestiškuosius ir pereinamojo tipo regionus. Šio metodo pagrindas - gyventojų tankumas $1 \mathrm{~km}^{2}$. Kaimiškasis regionas (ar grupè regionų) yra teritorinė gyvenviečių sistema. Jei NUTS 3 regionų klasifikacijoje kaimų gyventojai sudaro ne mažiau kaip 50 \% visų sistemos gyventojų, tai tokia regioninè sistema yra dominuojanti kaimiškoji sistema (Rural Development in the EU (...), 2013, p. 49). Tarpiniam regionui priskiriami, jei yra miestas, kur gyvena daugiau kaip 500000 žmonių ir tai sudaro ne mažiau kaip 25 \% visų regiono gyventojų. Šiuo požiūriu galima diskutuoti, kokiam regiono tipui 
priskiriama Lietuva, kuri pagal minètą regionų klasifikaciją priklauso vienam regionui. Kaimiškumą lengviau apskaičiuoti pagal apskričių ir rajonų teritorinius administracinius vienetus. Pvz., Vilniaus apskritis galètų būti priskiriama urbanizuoto regiono tipui, o Tauragès apskritis - kaimiškojo regiono tipui.

Lietuvoje pagal tradiciją, kuri gyvuoja dar nuo Lietuvos Didžiosios Kunigaikštystès laikų, kaimais laikomos visos gyvenamosios vietovès, kurios pagal valdovų privilegiją ar malonę, vèliau - pagal aukščiausios valdžios nutarimus nèra gavę miestų privilegijos ar teisès. Todèl iš dalies galima sutikti su glaustu biurokratiniu apibrěžimu, kuris apibrèžia, kad Lietuvoje visos gyvenvietès, kurios nèra miestai, yra kaimai. Toks apibrèžimas, be abejo, nepanaikina geografų ir kitų specialistų suformuluotos terminologijos. Taigi kaimas - tai gyvenamoji vietove, kurios dalis gyventojų verčiasi su žeme susijusiais darbais ar kitais kaimiškaisiais verslais, glaudžiai susiję su gamtine gyvenamaja aplinka, puoselejja tradicines vertybes, sudaro pirminès bendruomenès branduolị.

\section{Kaimų, kaip gyvenamosios vietos, raida Lietuvoje}

Pirmosios žmonių gyvenvietės atsirado dar žmonijos gyvavimo aušroje, kai pavieniai individai pajuto būtinumą burtis ị didesnes grupes. Tai buvo laikinos arba pastovios gyvenamosios vietos, kurių geografinę lokalizaciją dažniausiai lèmè medžioklès ir žvejybos plotai, vandens telkiniai. Vèliau, nusistovèjus ilgesniems taikos ir ramybès laikotarpiams, teritorijos apgyvendinimą labiau lèmé kiti veiksniai. Gyvenviečių - tiek miesto, tiek kaimo tipo - tyrimas sudaro neatskiriamą žmonijos istorijos dalị. Nesigilinant ị gyvenviečių raidos istoriją, galima teigti, kad kaimai daug amžių buvo vieninteliai ir pagrindiniai žmonių koncentracijos centrai. Daugelyje valstybių ir regionų juose koncentravosi pagrindinè teritorinių administracinių junginių žmonių masè. Tokia padètis išliko ir Lietuvoje, kurioje kaimų ir juose gyvenančių žmonių skaičius viršijo miestų ir miestiečių skaičių iki pat XX a. antrosios pusés.

Kaimų skaičiui ir jų tankumui didžiausios įtakos praeityje turèjo ekonominiai ir politiniai veiksniai, kurie nemažai priklausė ne tik nuo pačių kaimų bendruomenių, bet ir nuo politinių sprendimų, valstiečių ūkininkavimo formos, naujų žemės dirbimo ir gyvulių auginimo technologijų. Tą patị galima pasakyti ir apie dabartinị laikotarpị. Pirmieji didesni kaimai Lietuvos teritorijoje, kaip ir kitur, kūrèsi prie pilių, kurių dalis vèliau peraugo ị miestus. Taip gyventojai gynėsi nuo užpuolikų, nes pilių ir miestų sienos buvo patikimas prieglobstis antpuolių metu. Taip atsirado pastovios gyvenvietės - žmonių gyvenamųjų vietų teritorinė organizacija. Turèdama kai kuriuos materialinius įrenginius, kaip gyvenamuosius, visuomeninius, gamybinius ir negamybinius pastatus, įrengtus antropogeniniame landšafte, atskira 
gyvenviete tapo materialinių ir dvasinių vertybių kūrimo bei vartojimo, žmonių reprodukcijos centru. Be to, kaimai tapo svarbūs rekreacijos, poilsio, turizmo ir sporto renginių požiūriu.

Daugelị amžių kaimai dabartinès Lietuvos teritorijoje augo neribojamai plèsdamiesi teritorijoje ir didindami savo gyventojų skaičių - paprastai natūralios reprodukcijos būdu. Tik sustiprèjus centralizuotai kunigaikščių, vèliau - kitų valstybès vadovų valdžiai kaimų vystymasis pradètas reguliuoti baudžiavinių ir kitụ įstatymų pagrindu. Lietuvoje įbaudžiavinimo procesas, prasidejjęs X-XII a., galutinai ịsigalèjo $1413 \mathrm{~m}$., prièmus Horodlès unijos privilegiją, pagal kurią visi bajoro valstiečiai be jokių išlygų tapo baudžiauninkais (oficialiai baudžiavą $1447 \mathrm{~m}$. įteisino Kazimieras). Kaimų vystymuisi tai buvo esminis dalykas: be bajoro valios né vienas valstietis negalejo persikelti kitur, kurti naujos sodybos ir pan. Iki to laiko, be kaimo termino, egzistavo ir laukas. Bajoro sodyba su jo tarnų namais buvo vadinama kaimu. Laukas iki pat XVI a. reiškè valstiečių bendruomenę, kaip priešingybę kaimui, nors šių dienų supratimu ir viena, ir kita buvo kaimas, tik vienas - su bajoro sodyba, kitas - be jos (Rupas, Vaitekūnas, 1980, p. 16). XVI a. vietoj lauko juridiniuose dokumentuose jau vartojamas tik kaimo terminas. Taigi galima teigti, kad kaimo sąvoka Lietuvoje oficialiai atsirado tik daugiau kaip prieš 400 metų.

Valakų reforma, vykdyta XVI a., galutinai panaikino valstiečių teisę i jų nuosavybės likučius, atskyre feodalų ir valstiečių luomus. Netrukus daugiau nei pusė visų Lietuvos valstiečių tapo baudžiauninkais. Buvo sukurta rěžinè žemių sistema. Tai varžè kaimų vystymąsi. Siauri rèžiai, besitęsiantys nuo kaimų sodybų ir vieno savininko žemių padalijimas ị kelis sklypus, nutolusius vienas nuo kito, mažino žemių dirbimo našumą, jų panaudojimą.

Naujas kaimų vystymosi etapas prasidejo $1861 \mathrm{~m}$. panaikinus baudžiavą ${ }^{1}$, po 1863 m. antibaudžiavinio ir anticarinio sukilimų Lietuvoje ir Lenkijoje. Valstiečiams, vykdant $1861 \mathrm{~m}$. caro ịsaką, suteikta asmeninė laisvè, teisè išsipirkti žemę. Tačiau išlikę servitutai ir kiti ginčijami žemių naudojimo klausimai neišspręsti dar penkis dešimtmečius po baudžiavos panaikinimo. Be to, aštuntojo dešimtmečio pradžioje prasidèjo kaimų skirstymasis ị vienkiemius ${ }^{2}$. 1870-1904 m. Panemunės valsčiuje vienkiemiais išsiskirste 88 kaimai (sukurti 2159 vienkiemiai). Šiaurès Lietuvoje 1884-1904 m. 53 kaimai sukūrè 793 vienkiemius (Кофод, 1905, c. 244, 256-257). Dar labiau kaimus keitè su Lietuva susijusio (turejo dvarą Lietuvoje) Rusijos ministro pirmininko Piotro Stolypino parengta agrarinè reforma, kurios įstatymas priimtas $1906 \mathrm{~m}$. Vykdant šią reformą Vilniaus ir Kauno gubernijose

1 Užnemuneje ir Klaipėdos krašte, remiantis Napoleono kodeksu, baudžiava panaikinta 1807 m., Palangos valsčiuje - 1819 m.

2 Literatūroje kartais, kaip sinonimas, vartojama viensédžio sąvoka. Tai žemės sklypas su vienintele sodyba, kuri išlaikiusi kaimo vardą. 
1907-1914 m. sukurta 45701 vienkiemis (Rupas, Vaitekūnas, 1980, p. 33). Prasidèjęs Pirmasis pasaulinis karas šią reformą nutraukè. Vienkiemių ir mažų kaimų atsiradimas iš dalies pakeitè kaimų morfologiją, valstiečių gyvenimo ir darbo būdą.

Juridinès ir faktinès laisvès valstiečiams suteiktos tik XX a. pradžioje, 1918 m. paskelbus nepriklausomą Lietuvos Respubliką. Savanoriai, dalyvavę kovose už Lietuvos laisvę, nemokamai gavo žemès. Vykdant žemès reformą jos gavo ir dalis bežemių (amatininkų, tarnautojų, samdinių). Prasidèjo kaimų atgimimas: buvo statomi nauji gyvenamieji ir gamybiniai pastatai, tvarkomi keliai, kuriama kita infrastruktūra.

Remiantis 1918 m. statistika, Lietuvoje dar buvo 9604 kaimai, kurie neišskirstyti ị vienkiemius (Balčiūnas, 1938, p. 106). Tačiau pirmieji pareiškimai dẻl jų kūrimo gauti iškart po Nepriklausomybès kovų -1919 m. Norą išsiskirstyti į vienkiemius 1919-1939 m. pareiškė 9593 kaimai. Tais metais žemètvarkininkai sudare 216412 žemės sklypų, kuriuose įsikūre 159118 vienkiemių (Žemès ūkio (...), 1938, p. 339; Žemètvarka (...), 1940, p. 61). 1922-1939 m. kaimuose pastatyta 103332 gyvenamieji ir 183932 ūkiniai pastatai, kurie statyti daugiausia vienkiemiuose.

Pradètą žemės ūkio, kartu ir kaimų reformą nutraukè sovietinė okupacija ir Antrasis pasaulinis karas, kurio metu sudeginta, sugriauta nemažai kaimų. Okupacinè vokiečių valdžia Lietuvoje rekvizavo daug gyvulių, traktorių, kitų žemės ūkio padargų, grobė viską, kas tiko kariuomenei ar buvo reikalinga Vokietijai. Verta paminèti ir tai, kad dalị Lietuvos ūkių buvo numatyta perduoti kolonistams vokiečiams. Dalị žmonių išvežè prievartiniams darbams ị Vokietiją. Šiuos procesus sustabde tik tai, kad Vokietija karą pralaimèjo.

Dar labiau žemès ūkio ir kaimų vystymuisi pakenkẻ sovietinè žemès ūkio reforma, panaikinusi privačią nuosavybę ị žemę ir ịvedusi kolektyvinị žemès valdymą. Kaimų skaičiui ir jų tankumui bei dydžiui didelès įtakos turejo septintajame dešimtmetyje prasidèjęs kaimų pertvarkymas. Remiantis rajoninio planavimo schemomis turejjo būti visiškai panaikinti vienkiemiai, o jų gyventojai - sukelti ị gyvenvietes. Pastarosios suskirstytos ị centrines, pagalbines ir neplèstinas. Vienkiemių 1950 m. buvo apie 280 tūkst., 1970 m. - 250 tūkst. Žemių melioracijos pretekstu 1967-1979 m. nukelta 63,8 tūkst. vienkieminių sodybų. $1980 \mathrm{~m}$. jų dar buvo likę 145 tūkst. Gana sparčiai prasidèjęs vienkiemių nukèlimas vẻliau sulètėjo dèl valstybès skiriamų lèšų trūkumo ir dẻl nedidelio ekonominio efektyvumo.

1989 m. paskutinis visuotinis SSRS gyventojų surašymas parodè, kad kaimų skaičius išliko gana didelis, bet jų struktūra ir normali tinklo raida buvo sutrikdyti dèl planinio komandinio ūkio modelio taikymo ir esminių ekonomikos bei visuomenès gyvenimo dèsnių nepaisymo.

Jau daugiau kaip du dešimtmečius Lietuvos kaimai vystosi iš esmès tokiomis pačiomis sąlygomis, kokios jos buvo nepriklausomoje Lietuvoje Antrojo pasauli- 
nio karo išvakarèse. Kartu būtina pastebėti, kad Lietuvos tapimas Europos Sajungos nare, globalizacijos procesai neaplenke kaimų modernizavimo, jų gamybos specializacijos, infrastruktūros. Iš esmès pasikeitè gamybos intensyvumas, jos procesų modernizavimas, gyventojų aptarnavimo lygis ir jo formos. Kinta ir kaimų funkcijos, architektūra, žmonių gyvenimo būdas ir t. t. Dèl to galima sutikti su teiginiu, kad atsiranda naujas kultūrinis kraštovaizdis, būdingas daugeliui ekonomiškai išvystytų šalių (Roe, Taylor, 2014, p. 17). Lyginant dabartinius kaimų tyrimus su ankstesniais, ṣ̨̌ teiginị galima taikyti ir Lietuvai, kurioje ị kaimišką kraštovaizdị vis labiau skverbiasi urbanistiniai elementai. Čia iškyla svarbus valstybei uždavinys - kaimiškujų vertybių, ypač tų, kurios svarbios ne tik kaimiečiams, bet ir miestiečiams, išsaugojimas.

\section{Kaimų skaičius, dydis ir tankumas}

Kaimų skaičius jų raidos procese nuolat kito. Tai priklausė nuo daugelio veiksnių, bet pirmiausia nuo ūkininkavimo būdo, kurị nulèmè politinès visuomeninès sąlygos. Kaimus daugelis geografų ir demografų bandè suskaičiuoti dar XVI-XVII a. Šiuo požiūriu ypač svarbus buvo 1790 m. Lietuvos Didžiosios Kunigaikštystės gyventojų (dūmų) surašymas. Dar tikslesnis kaimų skaičius fiksuotas 1897 m. Rusijos imperijos pirmajame visuotiniame gyventojų surašyme. Remiantis jo duomenimis, surašymo metais dabartinès Lietuvos teritorijoje buvo 26482 kaimai, iš kurių to meto statistika išskyre 13201 kaimą, 676 bajorkaimius, 7439 vienkieminius kaimus (viensėdžius) ir vienkiemius bei 5166 užusienius (kaimus su keliomis sodybomis) (Rupas, Vaitekūnas, 1980, p. 57). 1959 m. gyventojų surašymo duomenimis, Lietuvoje buvo 25143 kaimai, 1970 m. - 24229 , 1979 m. - 23 570, 1989 m. - 19153 kaimai (Vaitekūnas, 2006, p. 163, 165). Atkūrus Lietuvos valstybę, visuotiniogyventojų surašymoduomenimis, $2001 \mathrm{~m}$. buvo 18461 , 2011 m. - 16762 kaimai. 1959-2011 m. iš Lietuvos žemėlapio išnyko 8381 kaimas.

Kaimų klasifikacija pagal dydị ịvairiose valstybėse yra skirtinga. Lietuvoje geografai taiko S. Vaitekūno (Вайтекунас, 1984; 1989) sukurtą klasifikaciją, kaip geriausiai atskleidžiančią šalies ekonomines-geografines ir demografines sąlygas.

Ilgalaikès kaimų raidos Lietuvoje analizė atskleide, kad kaimų skaičius nuolat mažèja (1 lentelè), nors teoriškai gyvenviečiu sistemoms būdingas didelio jų skaičiaus ir geografinio pasiskirstymo stabilumas. Pavienès kaimų dydžio grupès kito skirtingais tempais. Smulkių kaimų (turinčių nuo 1 iki 49 gyventojų) skaičius mažèjo léčiau nei kitu grupių. 1959 m. jų buvo 14 529, 2011 m. liko 13 151, t. y. sumažẻjo tik 1378 kaimais. Kaimų mažejimas apskrityse ir ịvairiose jų dydžio grupèse buvo gana skirtingas (2 lentelè, 2 pav.). 


\section{LIETUVOS KAIMŲ SISTEMA: KONCEPCIJA, SKAIČIUS, DYDIS, TANKUMAS,...}

1 lentele. Kaimų skaičius ir jų kitimas pagal dydi

( $K$ - kaimai, absoliučiaisiais skaičiais; $G$ - gyventojų skaičius, \%)

Table 1. Changes of the rural settlements by the size

( $K$ - number of settlements; $G$ - population in percent)

\begin{tabular}{|c|c|c|c|c|c|c|c|c|c|c|c|c|c|}
\hline \multirow{3}{*}{$\begin{array}{l}\text { Kaimo } \\
\text { dydis } \\
\text { (gyvent. } \\
\text { sk.) }\end{array}$} & \multicolumn{12}{|c|}{ Metai } & \multirow{3}{*}{$\begin{array}{c}\text { Kaimų } \\
\text { skai- } \\
\text { čiaus } \\
\text { kaita } \\
1959- \\
2011 \mathrm{~m} .\end{array}$} \\
\hline & \multicolumn{2}{|c|}{1959} & \multicolumn{2}{|c|}{1970} & \multicolumn{2}{|c|}{1979} & \multicolumn{2}{|c|}{1989} & \multicolumn{2}{|c|}{2001} & \multicolumn{2}{|c|}{2011} & \\
\hline & $\mathrm{K}$ & G & $\mathrm{K}$ & G & $\mathrm{K}$ & G & K & G & $\mathrm{K}$ & G & $\mathrm{K}$ & G & \\
\hline \multicolumn{14}{|c|}{ Smulkūs kaimai } \\
\hline $1-4$ & 1843 & 0,4 & 2562 & 0,5 & 3514 & 0,8 & 4597 & 1,2 & 4577 & 1,1 & 3654 & 0,9 & +1811 \\
\hline $5-9$ & 2433 & 1,2 & 2610 & 1,2 & 2931 & 1,7 & 2860 & 1,9 & 2362 & 1,5 & 3007 & 2,0 & +574 \\
\hline $10-24$ & 5032 & 5,2 & 5214 & 5,8 & 5193 & 6,5 & 4425 & 6,3 & 4680 & 6,6 & 4051 & 6,3 & -981 \\
\hline $25-49$ & 5221 & 11,5 & 4833 & 11,4 & 4040 & 10,8 & 2891 & 8,7 & 2680 & 8,3 & 2439 & 8,4 & -2782 \\
\hline \multicolumn{14}{|c|}{ Maži kaimai } \\
\hline 50-99 & 5518 & 23,9 & 4577 & 21,2 & 3134 & 16,3 & 1908 & 11,2 & 1737 & 10,4 & 1422 & 9,8 & -4096 \\
\hline \multicolumn{14}{|c|}{ Vidutiniai kaimai } \\
\hline 100-199 & 3711 & 30,7 & 3028 & 27,1 & 1889 & 19,6 & 1086 & 12,8 & 1019 & 12,4 & 934 & 13,1 & -2777 \\
\hline $200-499$ & 1252 & 21,0 & 1187 & 21,6 & 1115 & 24,2 & 983 & 25,9 & 1009 & 27,7 & 921 & 28,0 & -331 \\
\hline \multicolumn{14}{|c|}{ Dideli kaimai } \\
\hline $500-1000$ & 109 & 4,4 & 183 & 7,8 & 243 & 12,5 & 295 & 17,0 & 288 & 17,2 & 246 & 16,5 & +137 \\
\hline \multicolumn{14}{|c|}{ Stambūs kaimai } \\
\hline $1001+$ & 24 & 1,7 & 35 & 2,4 & 74 & 8,0 & 108 & 15,0 & 103 & 14,8 & 88 & 16,0 & +64 \\
\hline Iš viso & 25143 & 100 & 24229 & 100 & 22133 & 100 & 19153 & 100 & 18461 & 100 & 16762 & 100 & -8381 \\
\hline
\end{tabular}

Sudaryta, remiantis: 1989 m. visuotinio gyventojų surašymo duomenys. (1991). Vilnius, t. 1, p. 17-18; Vaitekūnas, 2006; Lietuvos gyventojai (...), p. 163; Lietuvos Respublikos 2011 metų gyventojų ir būstų surašymo rezultatai, 2013, p. 12

2 lentele . Kaimų pasiskirstymas pagal dydị apskrityse (absoliučiaisiais skaičiais ir procentais) $2011 \mathrm{~m}$.

Table 2. Distribution of the rural settlements according size in the regions by number and percent in 2011

\begin{tabular}{|c|c|c|c|c|c|c|c|c|}
\hline \multirow{2}{*}{ Apskritys } & \multirow{2}{*}{ Rodikliai } & \multirow{2}{*}{$\begin{array}{l}\text { Kaimai be } \\
\text { gyventojų }\end{array}$} & \multicolumn{5}{|c|}{ Kaimų dydis } & \multirow{2}{*}{ Iš viso } \\
\hline & & & Smulkūs & Maži & Vidutiniai & Dideli & Stambūs & \\
\hline \multirow{2}{*}{ Alytaus } & Sk. & 114 & 719 & 137 & 141 & 15 & 6 & 1018 \\
\hline & $\%$ & & 70,6 & 13,5 & 13,8 & 1,5 & 0,5 & 100,0 \\
\hline \multirow{2}{*}{ Kauno } & Sk. & 495 & 1472 & 206 & 279 & 43 & 24 & 2024 \\
\hline & $\%$ & & 72,7 & 10,2 & 13,8 & 2,1 & 1,2 & 100,0 \\
\hline \multirow{2}{*}{ Klaipèdos } & Sk. & 63 & 558 & 137 & 155 & 35 & 14 & 899 \\
\hline & $\%$ & & 62,1 & 15,2 & 17,2 & 3,9 & 1,6 & 100,0 \\
\hline \multirow{2}{*}{$\begin{array}{l}\text { Marijam- } \\
\text { polès }\end{array}$} & Sk. & 226 & 963 & 105 & 177 & 20 & 3 & 1268 \\
\hline & $\%$ & & 75,9 & 8,3 & 14,0 & 1,6 & 0,2 & 100,0 \\
\hline \multirow{2}{*}{ Panevėžio } & Sk. & 721 & 1639 & 125 & 194 & 32 & 6 & 1996 \\
\hline & $\%$ & & 82,1 & 6,3 & 9,7 & 1,6 & 0,3 & 100,0 \\
\hline
\end{tabular}


Stasys Vaitekūnas, Erika Čepienè

\begin{tabular}{|c|c|c|c|c|c|c|c|c|}
\hline \multirow{2}{*}{ Apskritys } & \multirow{2}{*}{ Rodikliai } & \multirow{2}{*}{$\begin{array}{l}\text { Kaimai be } \\
\text { gyventojų }\end{array}$} & \multicolumn{5}{|c|}{ Kaimų dydis } & \multirow{2}{*}{ Iš viso } \\
\hline & & & Smulkūs & Maži & Vidutiniai & Dideli & Stambūs & \\
\hline \multirow{2}{*}{ Šiaulių } & Sk. & 576 & 1496 & 148 & 236 & 23 & 9 & 1912 \\
\hline & $\%$ & & 78,2 & 7,7 & 12,3 & 1,3 & 0,5 & 100,0 \\
\hline \multirow{2}{*}{ Tauragès } & Sk. & 148 & 795 & 121 & 126 & 18 & 2 & 1062 \\
\hline & $\%$ & & 74,8 & 11,4 & 11,9 & 1,7 & 0,2 & 100,0 \\
\hline \multirow{2}{*}{ Telšių } & Sk. & 109 & 546 & 95 & 117 & 21 & 3 & 782 \\
\hline & $\%$ & & 69,8 & 12,1 & 15,0 & 2,7 & 0,4 & 100,0 \\
\hline \multirow{2}{*}{ Utenos } & Sk. & 1022 & 2446 & 90 & 143 & 11 & 1 & 2691 \\
\hline & $\%$ & & 90,9 & 3,3 & 5,4 & 0,4 & 0,0 & 100,0 \\
\hline \multirow{2}{*}{ Vilniaus } & Sk. & 727 & 2517 & 258 & 287 & 28 & 20 & 3110 \\
\hline & $\%$ & & 81,0 & 8,3 & 9,2 & 0,8 & 0,6 & 100,0 \\
\hline \multirow{2}{*}{ Iš viso } & Sk. & 4201 & 13151 & 1422 & 1855 & 246 & 88 & 16762 \\
\hline & $\%$ & - & 78,4 & 8,5 & 11,1 & 1,5 & 0,5 & 100,0 \\
\hline
\end{tabular}

Pastaba: I kaimų dydžių bendrą sumą kaimai be gyventojų neįskaičiuoti.

Sudaryta, remiantis: Lietuvos Respublikos 2011 metų gyventojų ir būstų surašymo rezultatai, 2013, p. 425-674

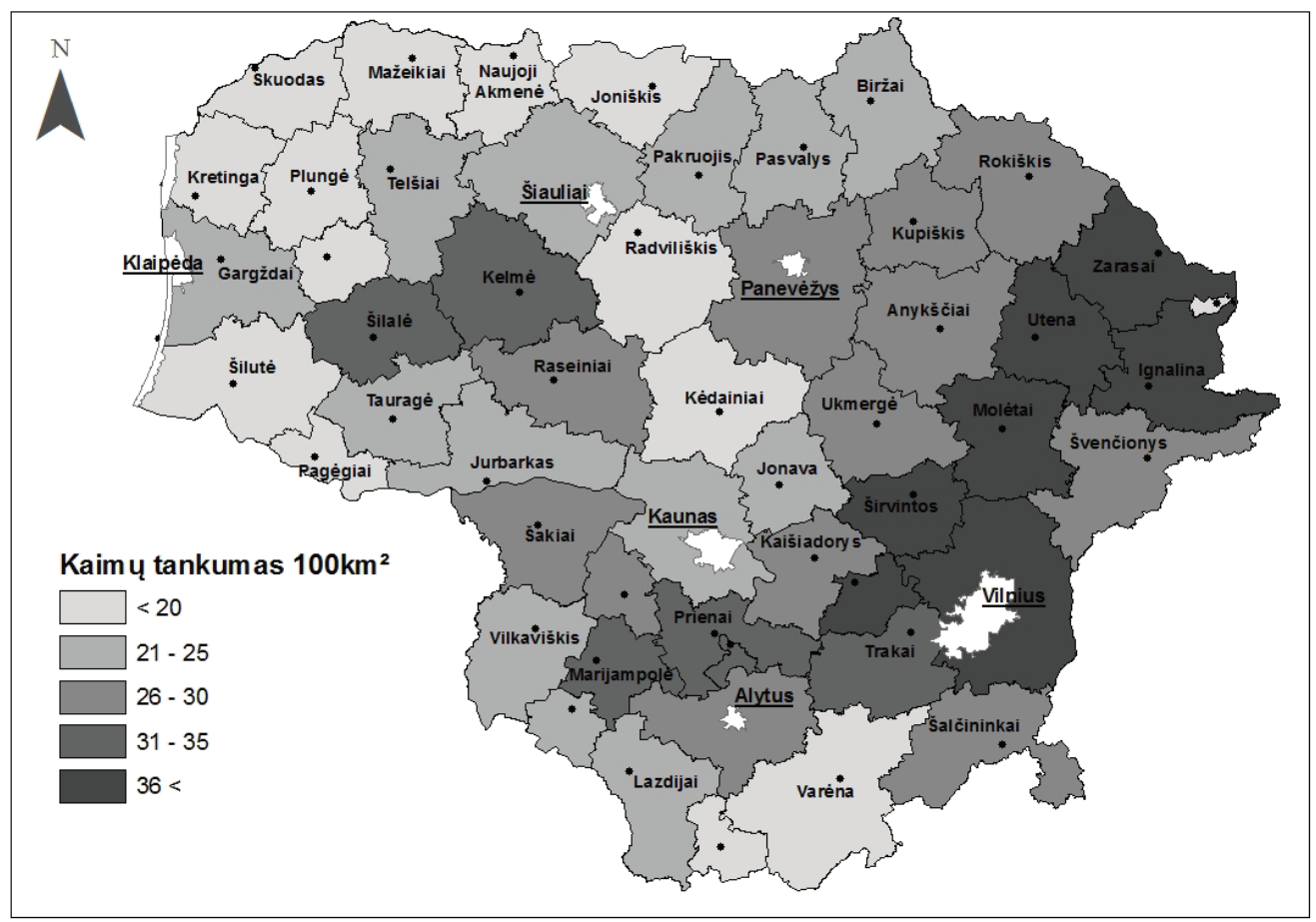

1 pav. Lietuvos kaimų tankumas rajonuose $2011 \mathrm{~m}$ (100 $\mathrm{km}^{2}$ tenka kaimų)

Fig 1. Density of the rural settlements by municipalities 2011 (villages per $100 \mathrm{~km}^{2}$ )

Šaltinis: Lietuvos Respublikos 2011 metų gyventojų ir būstų surašymo rezultatai, 2013, p. $425-627$

Source: Results of the 2011 Population and Housing Census of the Republic of Lithuania, 2013, p. 425-627 
Atkreipia dèmesį tas faktas, kad pačių smulkiausių kaimų (turinčių iki 5-ių nuolat juose gyvenančių žmonių) skaičius net padidejjo iki 2354, t. y. 1811 kaimų. Tokių smulkių kaimų 2001 m. buvo dar daugiau. Kai kuriuos jų jau galima laikyti vienkiemiais, kurie dar išlaikè senųjų kaimų vardus, ir viensėdžiais.

Mažų kaimų grupe (50-99 gyventojai) laipsniškai sumažejo daugiau nei trigubai: iš 5518 kaimų, registruotų per 1959 m. gyventojų surašymą, $2011 \mathrm{~m}$. liko tik 1422 , t. y. tik $25,8 \%$.

Vidutinių kaimų (100-499 gyventojai), kaip ir mažų, skaičius labiausiai sumažèjo - tiriamuoju laikotarpiu jų sumažėjo 2,8 karto. Be to, statistinė analizè atskleidè, kad sparčiau mažejo kaimų, turinčių mažesnị (iki 200 gyventojų) žmonių skaičių. Didesnių kaimų skaičius mažèjo gerokai lèčiau.

Priešingai kito didelių ir stambių kaimų skaičius - jis padidejjo daugiau kaip tris kartus. Stambių kaimų skaičius išaugo net 3,7 karto, nors bendras jų skaičius $2011 \mathrm{~m}$. sudare tik vos daugiau nei $0,5 \%$ visų kaimų.

Atlikus kaimų dydžių raidos analizę galima daryti tokias išvadas apie tiesioginę kaimų dydžių ir jų skaičiaus priklausomybę: 1) kuo mažesni kaimai - tuo didesnis jų skaičius; 2) mažesnių kaimų skaičius keičiasi sparčiau; 3) kaimų skaičius ir jų persiskirstymas tam tikruose klasteriuose sparčiai kinta.

3 lentele. Kaimų geografinis pasiskirstymas apskrityse $2011 \mathrm{~m}$.

Table 3. Geographical distribution of the rural settlements according regions 2011

\begin{tabular}{|c|c|c|c|c|c|c|c|}
\hline \multirow[b]{2}{*}{ Apskritys } & \multicolumn{2}{|c|}{ Plotas } & \multicolumn{2}{|c|}{ Kaimų skaičius } & \multirow[b]{2}{*}{$\begin{array}{c}\text { Kaimynystès } \\
\text { indeksas }\end{array}$} & \multirow{2}{*}{$\begin{array}{c}\text { Kaimų } \\
\text { tankumas } \\
(\text { kaimai / } \\
100 \mathrm{~km}^{2} \text { ) }\end{array}$} & \multirow{2}{*}{$\begin{array}{c}\text { Vienam } \\
\text { kaimui tenka } \\
\mathrm{km}^{2}\end{array}$} \\
\hline & $\begin{array}{l}\text { tūkst. } \\
\mathrm{km}^{2}\end{array}$ & $\%$ & $\begin{array}{l}\text { skai- } \\
\text { čiais }\end{array}$ & $\%$ & & & \\
\hline Alytaus & 5,4 & 8,3 & 1018 & 6,1 & 2,3 & 19 & 5,3 \\
\hline Kauno & 8,1 & 12,4 & 2024 & 12,1 & 2,0 & 25 & 4,0 \\
\hline Klaipėdos & 5,2 & 8,0 & 899 & 5,4 & 2,4 & 17 & 5,8 \\
\hline Marijampolès & 4,5 & 6,9 & 1268 & 7,6 & 1,9 & 28 & 3,5 \\
\hline Panevėžio & 7,9 & 12,1 & 1996 & 11,9 & 2,0 & 25 & 3,9 \\
\hline Šiaulių & 8,5 & 13,0 & 1912 & 11,4 & 2,1 & 22 & 4,5 \\
\hline Tauragès & 4,4 & 6,7 & 1062 & 6,3 & 2,0 & 24 & 4,2 \\
\hline Telšių & 4,3 & 6,6 & 782 & 4,7 & 2,4 & 18 & 5,6 \\
\hline Utenos & 7,2 & 11,0 & 2691 & 16,0 & 1,6 & 37 & 2,7 \\
\hline Vilniaus & 9,8 & 15,0 & 3110 & 18,5 & 1,8 & 32 & 3,1 \\
\hline Iš viso & 65,3 & 100,0 & 16762 & 100,0 & 2,3 & 26 & 3,9 \\
\hline
\end{tabular}

Pastaba: Kaimų tankumas ir jų teritorijos dydis skaičiuotas pagal bendrą apskričių plotą Skaičiuota, remiantis: Lietuvos Respublikos 2011 metų gyventojų ir būstų surašymo rezultatai, 2013, p. 425-674

Pirmają išvadą galima pagrịsti tuo, kad gyvenviečių, kaip ir dažnoje kitoje socialineje sistemoje, smulkesnių elementų visada yra daugiau nei stambesnių (Vaitekūnas, 1989, p. 32; Mayhef, 1997, p. 409). Šie pavieniai elementai sistemoje nevie- 
nodai svarbūs. Gyvenviečių dydžio ir jų skaičiaus kitimas patvirtina sistemų teoriją, kuri teigia, kad gyvenviečių, kaip ir bet kuriai kitai geografinei sistemai, būdingas nuolatinis vystymasis. Analizuojant Lietuvos kaimų, kaip gyvenviečių, sistemą, galima teigti, kad ji yra ekvifinalinè, t. y. linkusi išlaikyti tam tikrą pusiausvyrą tarp koncentracijos ir dekoncentracijos. Tuo tarpu smulkūs ir maži elementai yra mažiau atsparūs vidiniams ir išoriniams poveikiams: ekonominiams, socialiniams, ekologiniams. Šiuo požiūriu ypač svarbūs veiksniai yra infrastruktūra, inovacijos ị agrarinị sektorių, efektyvus žemės ūkio produkcijos intensyvumo augimas, gyvenviečių funkcijų kitimas ir pan. Dẻl šių priežasčių maži kaimai perkeliami ị smulkių kaimų kategoriją arba visiškai išnyksta (4 lentelè). Stabiliausi sistemoje yra vidutiniai ir dideli kaimai, jie turi tendenciją augti: pirmieji - iki didelių, antrieji - iki stambių. Kai kurie stambūs kaimai savo gyventojų skaičiumi lenkia netgi miestus. Antai Vilniaus rajone esantys Avižienių, Rudaminos, Didžiosios Riešès, Nemėžio kaimai turi daugiau kaip po 2000 gyventojų, Rudamina ir Pagiriai - daugiau nei po 3000. Didelių kaimų yra ir kitose apskrityse, ypač tose, kurių centrai yra didieji miestai. Čia kaimai koncentruojasi arčiau didelių miestų, su kuriais dažnai jungia bendra infrastruktūra, darbo ryšiai. Tą akivaizdžiai patvirtina ir kiti pastarujų metų duomenų tyrimai bei kartografavimas. D. Verkulevičiūtės-Kriukienès ir J. Galinienès (2014) teigimu, pvz., kaimai, esantys 5 km spinduliu nuo Klaipėdos, augs ir artimiausius du dešimtmečius. Galima prognozuoti, kad ir kitų didžiausių miestų ịtakai priklausantys kaimai išlaikys tokią vystymosi tendenciją.

Statistinè kaimų skaičiaus analizè taip pat rodo gana didelį skaičių (daugiau kaip 4 tūkst.) kaimų, kurie 2011 m. jau neturèjo nė vieno pastovaus gyventojo. Jų nereikètų skubotai laikyti išnykusiais. Tai gali būti ir kaimai su išlikusiomis be pastovių gyventojų sodybomis, kurios periodiškai ar epizodiškai lankomos buvusių jų gyventojų (šeimininkų) ar naudojamos kaip sezoninès poilsinès. Dalis jų priklauso miestiečiams, kurie į šias sodybas atvyksta tik retkarčiais.

Per kelis dešimtmečius keitėsi ne tik kaimų, bet ir juose gyvenančių žmonių skaičius. Dèl to kito ir vidutinis kaimų dydis (2 pav.). Taip 1959 m. vidutinis kaimo dydis Lietuvoje buvo 66, 1979 m. - 60 žmonių. Lietuvos nepriklausomybès atkūrimo išvakarėse kaimo vidutinis dydis išaugo iki 62 žmonių. Tai galima sieti su sparčiu bendro gyventojų skaičiaus augimu ir sulètejjusia jų migracija ị miestus. $2001 \mathrm{~m}$. vidutinis kaimų dydis buvo 53 žmonès, 2011 - beveik 54. Toks statistinis kaimo vidutinio dydžio pokytis nulemtas bendro kaimų skaičiaus mažèjimo, t. y. smulkių kaimų gyventojų persikèlimo ị didesnius. Jei kaimų skaičius būtų išlikęs toks pat kaip ir 2001 m., tai 2011 m. vidutinis kaimo dydis būtų buvęs tik 53 žmonès, t. y. išlikęs toks pat kaip ir prieš dešimtmetị. Per kelis šimtmečius sumažejo ne tik vidutinis kaimo dydis, bet kito ir vienam kaimui priklausančios teritorijos dydis: mažejjant kaimų skaičiui, jų užimami plotai didèjo, nes susiliedavo dviejų ar daugiau kaimų laukai. 
4 lentelè. Kaimų skaičius pagal jų dydi (gyventojų skaičių) Lietuvoje

Table 4. Number of rural settlements acording the size (population number) in Lithuania

\begin{tabular}{|l|l|l|l|l|l|l|l|l|}
\hline \multirow{2}{*}{ Kaimai } & \multicolumn{3}{|c|}{ Kaimai } & \multicolumn{2}{c|}{$\begin{array}{c}\text { Gyventojai } 2001 \\
\text { m. }\end{array}$} & \multicolumn{2}{c|}{ Kaimai $2011 \mathrm{~m}$} & \multicolumn{2}{c|}{ Gyventojai $2011 \mathrm{~m}}$. \\
\cline { 2 - 10 } & \multicolumn{1}{|c|}{ Skaičiai } & $\%$ & Skaičiai & $\%$ & Skaičiai & $\%$ & Skaičiai & $\%$ \\
\hline $1-4$ & 3788 & 20,5 & 9131 & 0,8 & 3654 & 21,8 & 8862 & 0,9 \\
\hline $5-9$ & 3150 & 17,1 & 21381 & 1,8 & 3007 & 17,9 & 20252 & 2,0 \\
\hline $10-24$ & 4496 & 24,3 & 70983 & 6,2 & 4051 & 24,2 & 63719 & 6,3 \\
\hline $25-49$ & 2871 & 15,5 & 100554 & 8,7 & 2439 & 14,5 & 84957 & 8,4 \\
\hline $50-99$ & 1737 & 9,4 & 120079 & 10,4 & 1422 & 8,5 & 99128 & 9,8 \\
\hline $100-199$ & 1019 & 5,5 & 142492 & 12,4 & 934 & 5,6 & 132638 & 13,1 \\
\hline $200-499$ & 1009 & 5,5 & 318885 & 27,7 & 921 & 5,5 & 283805 & 28,0 \\
\hline $500-999$ & 288 & 1,6 & 197924 & 17,2 & 246 & 1,5 & 167587 & 16,5 \\
\hline $1000-1999$ & 85 & 0,5 & 115250 & 10,0 & 70 & 0,4 & 97078 & 9,6 \\
\hline $2000-4999$ & 18 & 0,1 & 55795 & 4,8 & 17 & 0,1 & 49186 & 4,9 \\
\hline$\geq 5000$ & - & - & - & - & 1 & 0,0 & 5006 & 0,5 \\
\hline Iš viso & 18461 & 100,0 & 1151874 & 100,0 & 16762 & 100,0 & 1012218 & 100,0 \\
\hline
\end{tabular}

Šaltinis: Lietuvos Respublikos 2011 metų gyventojų ir būstų surašymo rezultatai, 2013, p. 12

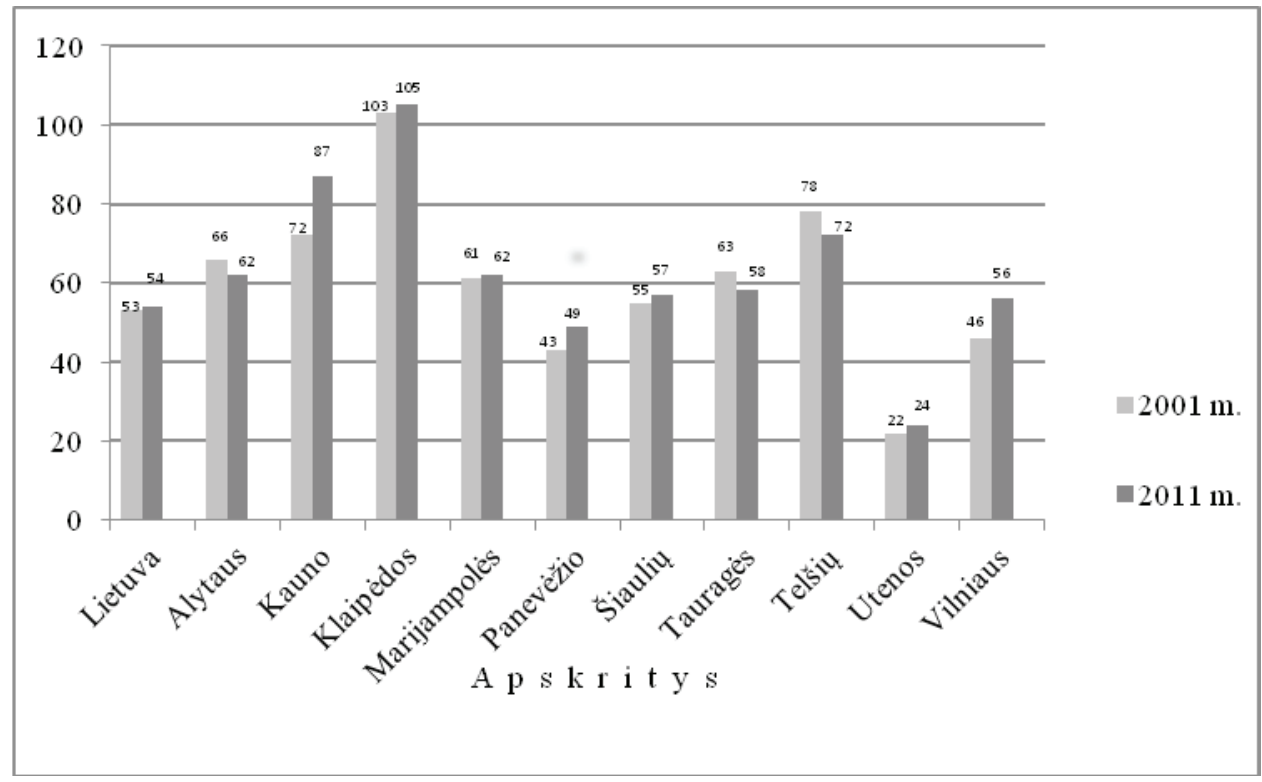

2 pav. Vidutiniai kaimų dydžiai apskrityse $2001 \mathrm{~m}$. ir $2011 \mathrm{~m}$.

Fig. 2. Average of the rural settlement size by regions in 2001 and 2011

Šaltiniai: Vaitekūnas, 2006, p. 165; Lietuvos Respublikos 2011 metų gyventojų ir būstų surašymo rezultatai, 2013, p. 425-627 


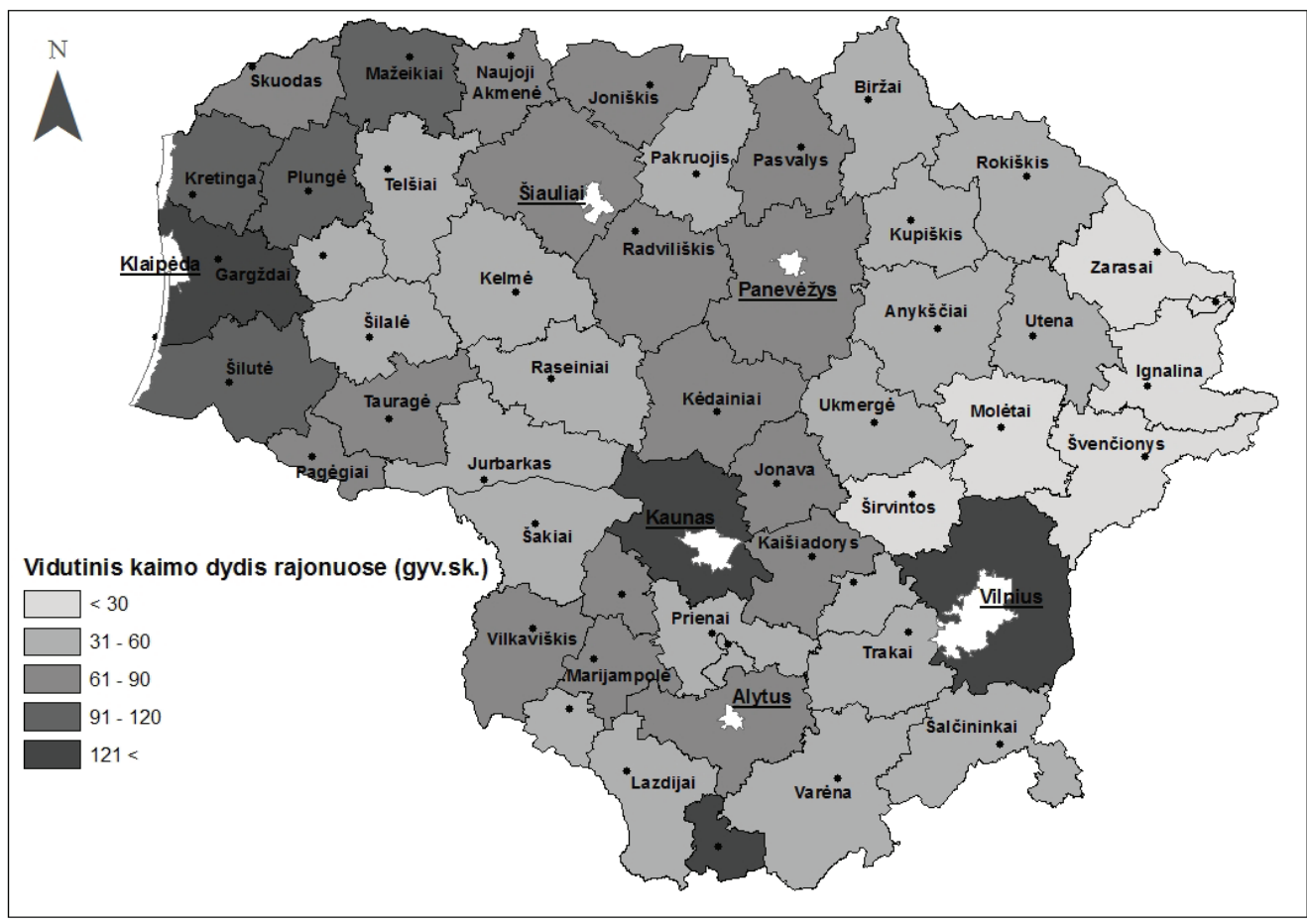

3 pav. Vidutinis kaimų dydis Lietuvoje pagal gyventojų skaičių $2011 \mathrm{~m}$.

Fig. 3. Average size of the Lithuanian rural settlements according population number, 2011

Šaltinis: Lietuvos Respublikos 2011 metų gyventojų (...), 2013, p. 425-627

Atlikus kaimų dydžių analizę pagal apskritis pastebimas tam tikras dėsningumas: šiek tiek kintant vidutiniam gyvenvietès dydžiui apskrityse jis išlieka gana pastovus, t. y. apskrityse šie rodikliai išlieka ilgam. Mažiausi kaimai dèl gamtinių geografinių sąlygų (didelis miškingumas, ežerų gausa, dažna geomorfologinių sąlygų kaita) yra Rytų Lietuvoje, ypač Utenos apskrityje. Čia vidutinis kaimų dydis vidutiniam Lietuvos kaimui nusileidžia daugiau kaip du kartus (3 pav.).

Stambiausi kaimai dėl istoriškai susiklosčiusių aplinkybių yra Vakarų Lietuvoje. Taip Klaipėdos apskrityje vidutinis kaimo dydis - daugiau kaip 100 žmonių. Tokie dėsningumai užfiksuoti dar XVIII a. (Вайтекунас, 1984, с. 70-71), kai dauguma žmonių gyveno kaimuose. Mažiausi kaimai (vidutiniškai 45-55 žmonès vienoje gyvenvietėje) buvo Vilniaus ir Ukmergès apskrityse, kiek didesni - Kauno ir Trakų apskrityse. Šis dėsningumas pastebètas ir vèliau, po Antrojo pasaulinio karo (pvz., Vaitekūnas, 1980, p. 49). Tam tikruose rajonuose šie skaičiai dar labiau skiriasi. Antai Kretingos rajone vidutinis kaimo dydis 2011 m. buvo 120 žmonių, 
Šilutès rajone - 92, o Rytų Lietuvos Molètų ir Ignalinos rajonuose - tik 20. Taigi galima teigti, kad kaimų gyventojų skaičiaus kaita yra ilgalaikè tendencija.

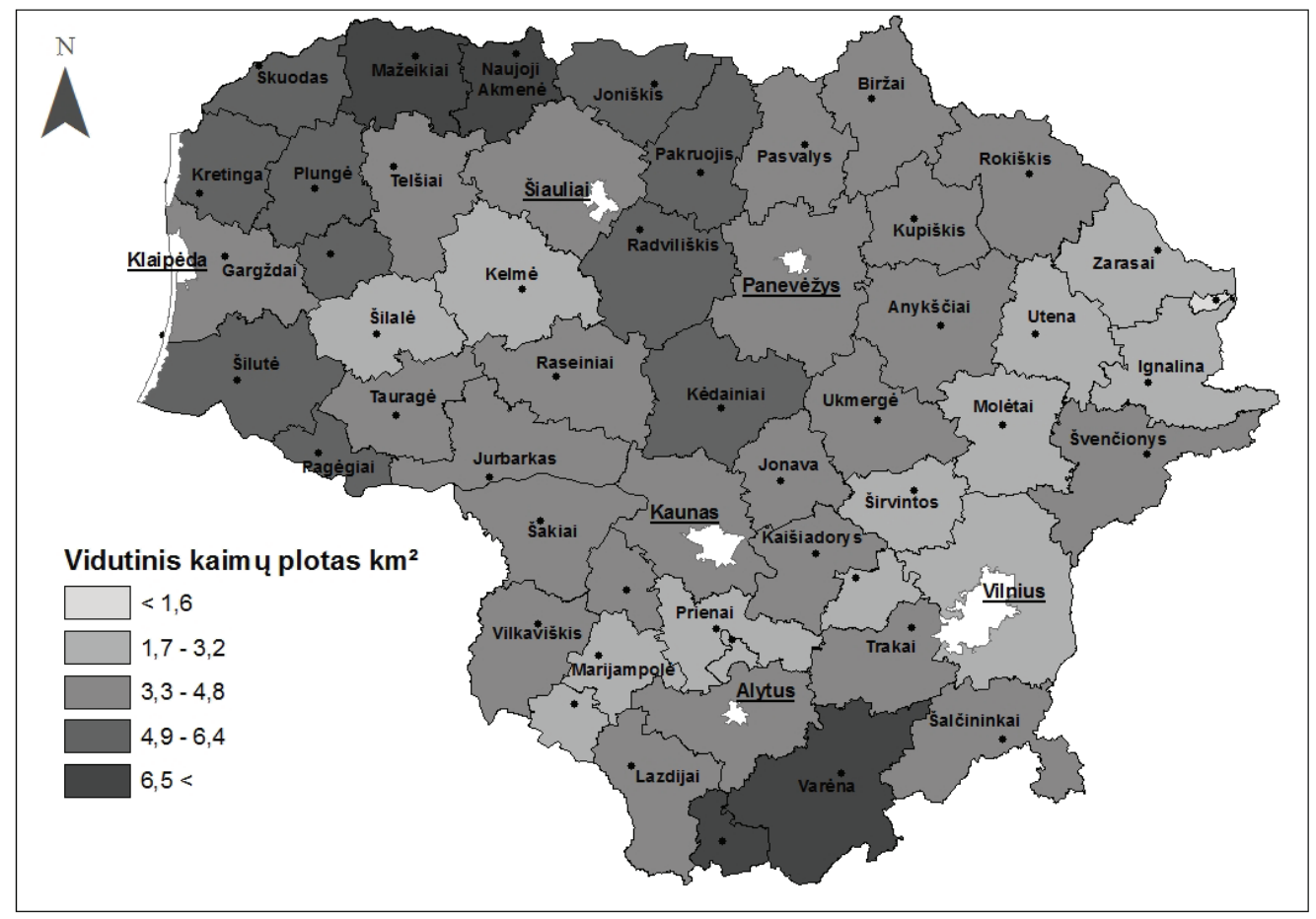

4 pav. Vidutinis kaimų plotas Lietuvos rajonuose $2011 \mathrm{~m} .\left(\mathrm{km}^{2}\right)$

Fig. 4. Size average of the village in Lithuanian regions 2011 according territory, $\mathrm{km}^{2}$ Šaltinis: Lietuvos Respublikos 2011 metų gyventojų (...), 2013, p. 425-627

Kaimų dydžių analizė leidžia pastebèti dar vieną tendenciją, kuri išvystytose Vakarų šalyse susiformavo dar XX a. pradžioje. Pastebima, kad didesni kaimai yra būtent tose apskrityse, kurios turi didesnius ir sparčiau nei kiti miestai besivystančius centrus. Tai susiję su tuo, kad pagerèjus susisiekimo infrastruktūrai dalis miestiečių persikelia gyventi ị priemiestinius, nuo centro nutolusius kaimus. Juose kuriasi ir iš kitų rajonų atvykstantys žmonès, kurie čia atranda palankesnes gyvenimo sąlygas. Dèl to ir Klaipėdos bei Vilniaus apskričių vidutinis kaimo dydis išaugo būtent tokių priemiestinių gyvenviečių sąskaita.

Toks kaimų vidutinių dydžių pokytis iš dalies gali būti paaiškinamas gyvenviečių dydžių stabilumu. Kita vertus, negalima pamiršti to, kad ịvairių dydžių kaimai transformuojasi pereidami iš vienos dydžio grupès ị kitą. Be to, kinta ir kaimų skaičius. Taigi galima daryti išvadą, kad kaimo žmonių skaičiaus mažejimas tiesiogiai veikia ir pačių kaimų skaičių. 
Kaimų ekonominiam ir socialiniam vystymui įtakos turi ne tik jų gyventojų skaičius, bet ir jų užimama teritorija bei konfigūracija (4 pav.). Lietuvoje, priešingai nei daugelyje Vakarų Europos šalių, šie klausimai beveik neanalizuoti, nors nuo pačios gyvenvietė ir jai priklausančios teritorijos dydžio bei ribų priklauso socialinè infrastruktūra, dirbamų laukų išsidèstymas, jų panaudojimo intensyvumas. Pastebèta, kad labiausiai nuo gyvenvietės nutolę laukai intensyviai naudojami mažiau dèl juos pasiekti būtino atstumo ir kuro taupymo. Paprastai maksimaliai dirbami, tręšiami, labiau prižiūrimi laukai yra arčiausiai gyvenvietès. Be to, tam tikrų laukų „specializaciją“ dèl kaimų ribų konfigūracijos lemia kelių tinklas, jų pasiekiamumas.

Lietuvos kaimų plotai ir jų konfigūracija ịvairiuose regionuose yra skirtinga. Tai priklauso nuo reljefo, miškingumo, istorinių ir ekonominių sąlygų. Vidutinis Lietuvos kaimo plotas, įskaičiuojant vandens plotus, miškus, karjerus, kelius ir pan., sudaro apie $3,9 \mathrm{~km}^{2}$. Apskrityse šis skaičius skirtingas. Didžiausius plotus kaimai užima Klaipèdos $\left(5,8 \mathrm{~km}^{2}\right)$, Tauragès $\left(5,6 \mathrm{~km}^{2}\right)$ ir Šiaulių $\left(4,5 \mathrm{~km}^{2}\right)$ apskrityse. Mažesni nei Lietuvos vidurkis kaimų plotai yra Marijampolès $\left(3,5 \mathrm{~km}^{2}\right)$, Utenos $\left(2,7 \mathrm{~km}^{2}\right)$ ir Vilniaus $\left(3,1 \mathrm{~km}^{2}\right)$ apskrityse. Mažiausių kaimų juosta nuo Zarasų ir Ignalinos rajonų tęsiasi link Marijampolès ir Šakių. Didesni kaimų plotai yra Šiaurès Vakarų regione ir miškinguose Pietų Lietuvos rajonuose. Kai kuriuose rajonuose pastebimas dar didesnis nuokrypis nuo Respublikos vidurkio. Antai Akmenès rajone vidutinis kaimo dydis yra net 7,4 km², Mažeikių $-7,2 \mathrm{~km}^{2}$. Mažiausi kaimai yra Molètų $\left(2 \mathrm{~km}^{2}\right)$, Širvintų $\left(2,6 \mathrm{~km}^{2}\right)$, Vilniaus $\left(2,3 \mathrm{~km}^{2}\right)$ rajonuose. Galima daryti išvadą, kad vidutinis kaimo ploto rodiklis yra proporcingas artimiausios kaimynystès indeksui.

Kaimo žmonių socialinei ir ekonominei infrastruktūrai tobulinti svarbus ir artimiausios kaimynystės indeksas, kuris rodo vidutinį atstumą tarp tiriamos teritorijos gyvenviečių, kuris apskaičiuojamas pagal formulę (Vaitekūnas, 1989, p. 51):

$$
D=\sqrt{\frac{n}{k}},
$$

kur: $D$ - vidutinis nuotolis;

$n$ - teritorijos plotas;

$k$ - gyvenviečių skaičius.

Vidutinis atstumo tarp Lietuvos kaimų indeksas $1959 \mathrm{~m}$. buvo 1,6 km, 2011 m. - 2,3. Šis indeksas taip pat rodo, kad dalis kaimų per šešis pastaruosius dešimtmečius išnyko. Tam tikrose apskrityse jis svyruoja nuo 1,6 iki 2,4 (3 lentelè). 
Kaimų sistemos tyrimai yra aktualūs ir kaimų gyventojų aptarnavimo sistemos vystymui, bendrosios infrastruktūros tobulinimui. Stambūs miestai ir mažesni rajonų centrai tampa pagrindiniais aptarnavimo tiekejais. Dėl to tyrime bandyta nustatyti atstumus nuo tokių centrų iki kaimų. Jie rajonuose yra nevienodi. Taip, pvz., Joniškio rajone seniūnijų centrai nuo rajono centro nutolę vidutiniškai $15 \mathrm{~km}$, Kèdainių rajone - daugiau kaip $17 \mathrm{~km}$, Varẻnos - $21 \mathrm{~km}$, Kauno - daugiau kaip 18 km. 16-a ir daugiau kilometrų seniūnijų centrai yra nutolę Molètų, Telšių, Biržų rajonuose. Didžiausias šiuo požiūriu vidutinis atstumas yra Jurbarko rajone - net $29 \mathrm{~km}$.

Kai kuriuose rajonuose pastebima, kad tam tikros seniūnijos gerokai viršija minètus vidutinius nuotolius. Antai Juodaičių seniūnija nuo Jurbarko nutolusi net $70 \mathrm{~km}$, o šio rajono Veliuona - $36 \mathrm{~km}$. Varènos rajone nuo rajono centro Valkininkai ir Merkinè yra nutolę daugiau kaip 29 km. Panašių „anomalijų“ (nukrypimų nuo vidutinio nuotolio) yra ir kituose rajonuose.

Tokie vidutiniai seniūnijų centrų atstumai nuo rajono centro nulemti kelių veiksnių: rajono konfigūracijos, rajono centro geografinès padèties, kelių tinklo, reljefo, teritorijos reljefo raižytumo, miškingumo, pačiu gyvenviečių specifikos.

Gyvenviečių fizinis nuotolis dar neparodo realaus nuotolio, t. y. rajono centro pasiekiamumo laiko ir materialinių sąnaudų požiūriu. Dalis kaimų, net būdami fiziškai netoli rajonų centrų, yra nepatogioje kelių sistemoje, todèl žmonès, norèdami gauti jiems būtinas paslaugas, kartais turi ịveikti didelį atstumą, daryti lankstą, nes nèra tiesioginio susisiekimo. Todèl optimizuojant gyventojų aptarnavimą teritoriniu požiūriu būtina atsižvelgti ne tik ị vidutinius atstumus, bet ir ị realią situaciją.

\section{Išvados}

Kaimai, atsiradę kartu su žmonių (homo sapiens) pasirodymu Žemèje, yra seniausia gyvenviečių forma. Pagrindinè kaimų funkcija amžiams slnkant išlieka ta pati - gaminti maistą, tiekti žemès ūkio produkciją kaip žaliavą ịvairioms pramonės šakoms. Lietuvos kaimų sistemos analizè leidžia daryti išvadas, kurios susijusios su jų vystymosi tendencijomis dabartiniame etape:

1. Dèl kaimų apibrèžimo ir jų statuso bendrojoje gyvenviečių sistemoje diskutuoja ịvairių mokslo sričių specialistai ir praktikai. Jų apibréžimus ir kaimiškumo kriterijus dažnai ,diktuoja“ atskirų šalių gyvenviečių istorinė raida, jų specifika, tyrinètojų nuostatos, jų požiūris ị tiriamą objektą. Todèl ieškoti bendro apibrěžimo, kuris tiktų visiems laikams ir visoms šalims, 
beprasmiška. Dėl to tyrimuose dažnai pasitenkinama kriterijumi: kas ne miestas - tas kaimas.

2. Nors gyvenviečiu sistemos yra inertiškos, dideli ekonominiai ir politiniai ịvykiai gali turèti ịtakos jų stabilumui. Bendroje gyvenviečių sistemoje labiau pažeidžiami ir ị šiuos įvykius jautriau reaguoja kaimai. Tai lemia jų specifinès ypatybès: dydis, silpnesni tarpusavio sisteminiai ryšiai, didelis priklausomumas nuo miestų. Pačioje kaimų sistemoje labiausiai pažeidžiami gyventojų skaičiumi smulkūs ir maži elementai bei labiau nutolę nuo stambių sistemos branduolių.

3. Lietuvos kaimų vystymąsi lèmé tokie svarbūs ekonominiai ir politiniai sukrètimai kaip du pasauliniai karai, esminès ekonominès bei socialinès reformos (baudžiavos panaikinimas, Valakų ir Stolypino, XX a. pradžios ir pabaigos žemès reformos, sovietinė kolektyvizacija ir jos žlugimas). Joms vykstant keitėsi kaimų dydžiai, planinė struktūra, teritorinis pasiskirstymas, todèl kito ir kaimų funkcijos, gyventojų sudètis, kaimiškieji kraštovaizdžiai.

4. Dabartiniame, XXI a. pradžios, etape kaimų vystymuisi didžiausią ịtaką daro sparčiai kintančios darbo priemonès, technologinès ir techninės inovacijos, susijusios su mokslo pažanga, urbanizacija ir globalizacija. Naujų technologijų ir efektyvesnès technikos taikymas žemės ūkyje lemia dalies kaimų dydžio mažèjimą. Didžiųjų Lietuvos miestų priemiestinèse zonose pastebimas dalies kaimų stambejimas: miestiečiai keliasi ị juos dẻl palankesnė gamtinès ir gyvenamosios aplinkos. Pastebima ryški kaimų dydžių tarpusavio persiskirstymo tendencija: 1959-2011 m. didelių ir smulkių kaimų skaičius didèjo mažų ir vidutinių kaimų sąskaita. Dalis vidutinių kaimų susmulkejjo, dalis pateko ị didelių gyvenviečių grupę. Daugiausia mažų kaimų yra Šiaurès Rytų Lietuvoje, ypač Utenos, Panevėžio ir Vilniaus apskrityse. Utenos apskrityje vidutinis kaimo dydis daugiau kaip du kartus mažesnis už vidutinị Lietuvoje. Stambiausi kaimai dažnesni Vakarų Lietuvoje, ypač Klaipėdos apskrityje. Nuo kaimų skaičiaus, jų tankumo priklauso ir artimiausios kaimynystès indeksas.

5. Kaimų tankumą, jų dydị lemia ir didžiųu, sparčiai besivystančių miestų ịtaka. Jų ịtakos zonose kaimai auga gyventojų, atvykstančių iš periferinių zonų, taip pat miestiečių, kurie savo gyvenamaja vieta pasirinko priemiestinius kaimus, sąskaita. Kaimų dydžių kaitai įtakos turi ir jų atstumas ne tik nuo didžiųų miestų, bet ir nuo savo administracinių rajonų centrų. Vidutinis kaimų atstumas nuo jų ịvairiuose rajonuose yra skirtingas: Joniškio 
rajone seniūnijų centrai nuo rajono centro nutolę vidutiniškai $15 \mathrm{~km}$, Kauno $-18 \mathrm{~km}$, Varènos $-21 \mathrm{~km}$. Šis fizinis nuotolis nerodo faktinio nuotolio, nes kelių kokybė, jų konfigūracija, centro geografinė padėtis rajono teritorijoje, laikas, būtinas pasiekti centrą, gali „nutolinti“ jo pasiekiamumą. Kai kurie seniūnijų centrai ir pavieniai kaimai nuo rajono centro nutolę net iki $70 \mathrm{~km}$. Kaimų atstumo nuo pagrindinių aptarnavimo centrų ir artimiausios kaimynystės indeksas yra svarbus kuriant infrastruktūros tinklą.

Gauta 20140323

Pasirašyta spaudai 20140701

\section{Literatūra}

Balčiūnas, V. (1938). Lietuvos kaimų žemès tvarkymas. Kaunas.

Česnavičius, D. (1998). Priemiestinès zonos ir jų nustatymo kriterijai. Geografija, nr. 34.

Goodal, B. (1987). Dictionary of Human Geography. London: Penguin Books.

Hoggart, K., Buller, H., Black, R. (1995). Rural Europe: Identity and Change. London: Arnold.

Kiełczewska-Zalieska, M. (1974). Geografia osadnictwa. Warszawa: PWN.

Krupickaitè, D. (1999). Lietuvos urbanizacijos geografinès problemos. Daktaro disertacija. KU-VU.

Lietuvos Respublikos 2011 metu gyventoju ir būstu surašymo rezultatai. (2013). Vilnius: LSD.

Mayhew, S. (1997). Dictionary of Geography. Oxford: Oxford University.

Roe, M., Taylor, K. (2014). New Cultural Landscapes. London: Routledge.

Rupas, V., Vaitekūnas, S. (1980). Lietuvos kaimo gyventojai ir gyvenvietès. Vilnius: Mintis.

Rural development in the EU - Statistical and Economic Information. (2013). Report 2013. European Union.

Szymańska, D. (2009). Geografia osadnictwa. Warszawa: PWN.

Trakymas, A., Vaitekūnas, S. (2006). Kaimas. Visuotinè lietuviu enciklopedija, t. 9. Vilnius.

Ubarevičiene, R., Burneika, D., Kriaučiūnas, E. (2012). The sprawl of Vilnius city - establishment and analysis of growing urban region. Annales Geographicae, no. 43, 44 .

Vaitekūnas, S. (1989). Gyvenviečiu geografija. Vilnius: VU.

Vaitekūnas, S. (2006). Lietuvos gyventojai per du tūkstantmečius. Vilnius: MELI.

Verkulevičiūtè-Kriukienė, D., Galinienè, J. (2014). Klaipėdos miesto ir priemiesčių zonų gyventojų ir gyvenviečiu plètra. Tiltai, nr. 2.

Žemès ūkio ministerijos metraštis, 1918-1938. (1938). Kaunas.

Žemètvarka ir melioracija. (1940). Kaunas.

1989 m. visuotinio gyventojų surašymo duomenys. (1991). T. 1. Vilnius.

Vaitekūnas, S. (2006). Lietuvos gyventojai per du tūkstantmečius. Vilnius: MELI.

Вайтекунас, С. (1984). Сельское расселение: К проблеме величины поселков. Geografija, t. 20.

Кофод, А. (1905). Крестьянские хутора на надельной земле, т. 1. С. Петербург. 


\title{
LITHUANIAN RURAL SETTLEMENTS SYSTEM: CONCEPTION, THE NUMBER, SIZE, DENSITY, LOCATION, CHANGES
}

\author{
Stasys Vaitekūnas, Erika Čepienè
}

Summary

A study of is an important fact that the settlements systems quantitative, qualitative and the structure and spatial distribution are influenced by the economic and social development, developmental stability. In the framework of the joint settlements and villages is vital for the system, although the cities are the main intellectual, cultural and economic development centers. Regional planning and regional policy is important to know the scale of each different system, their structures, and even the location and value of the individual the most important elements of the common system. It may be asserted that the settlements, their systems, and the country's economic, social and even political development there is a tight mutual dependency.

First rural settlements (habitations) emerged together with the people (homo sapiens) and primitive society performing on Earth, is the oldest form of settlements. In this respect, the villages are not only economic, but social and historical category also. The main function of the villages in the course of the age remains the same - to produce food, the supply of agricultural products, as a raw material for a variety of industries.

Geographical studies on the system of villages are important not only to science, geography, but also economists, sociologists, professionals of social and technical infrastructure, and others, forming the State budget, are considering investments in various economic sectors. The purpose of the article is preparing for the actual substance, relevant not only in theory but also in practice in geography.

The number and structure of the Lithuanian villages are changing steadily in the time and space. But the biggest changes took place in the $20^{\text {th }}$ century. The changes were related with at least three major agrarian reform. In addition, the villages and the development of agriculture have been affected by the two world wars, the land reform of the Soviet Union, the abolition of private property and collectivization at the time of Soviet occupation. In this point of view the development of villages in Lithuania was different from that of Western Europe took place in which this development had on the character of evolution.

At 1897 the general population census data in Lithuania was 26.5 thousand rural settlements. At $20^{\text {th }}$ century the number changed considerably and quantity of rural settlements was rapidly declining. A significant influence on the number 
of rural settlements had and forcible wrapping up of steadings and small hamlets. 1959-2011 out of the map disappeared 8381 rural settlement. The decline in the size of the groups in their villages has been different. The fastest decrease was declining number of small villages (some of them extinct). The group of big and utmost villages grew up at the same time. Their growth was determined due to the large number of the urban population migration to the more attractive suburban areas. In addition, points out that in the course of the history most stable villages of the system remained out there where the villages are larger, i.e., the Western and Central Lithuania. Small and small villages dominated in the East and South part of the country.

Lithuanian village system analysis allows state conclusions with regard to the current stage of its development trends:

1. The definition of the status of the villages, and the single settlement system is discussed in a variety of scientific fields for professionals and practitioners. The definitions and the criteria for their rurality often "dictate" the historical evolution of the settlements, their particularity, as well as the attitudes of the researchers, their approach to the object. So the search for a common definition, which applies for all historical periods, and to all the countries is meaningless. Therefore, research is often applicable a satisfactory criterion is: what is not a city is the village.

2. Although the settlement system is stagnant but the big economic and political events can affect their stability. The rural settlement is more sensitive and more vulnerable comparing with the total settlement system. This is due to their specific properties: size, topographic situation, more weak intersystem contacts, strong dependence on cities.

3. The development of the Lithuanian villages has led to dramatic economic and political shocks, such as the two world wars, fundamental economic and social reforms (cancellation of serfdom, Wallach and Stolypin's reforms, the reforms of beginning and end of the $20^{\text {th }}$ century, the Soviet collectivization and its collapse). All reforms changed the structure and functions of the villages, its network, density, territorial distribution, etc. In connection with it the rural landscapes lost some agricultural features, and approach to urban.

4. In the current stage of the beginning of the 21 st century, the villages development have the greatest influence on the rapidly changing labour means, technological and technical innovation, the development of the sciencerelated, urbanization and globalization. The implementation of new technologies and more efficient techniques in agriculture leads to a decrease in the size of the villages. The part of villages, attracting the population and 
increasing it number are located in the suburb areas of cities and larger towns of Lithuania. The reason of it is the number of the town people moving from cities to rural places due to the convenient natural and living environment. The redistribution among of the different size group of villages have bright trend - 1959-2011 the number of large and small villages have increased due to the number of decreasing of medium-sized villages. Lastmentioned part of the villages switched to a group of large settlements. The small villages predominate in the North-Eastern Lithuania, particularly in Utena, Panevezzys and Vilnius counties. The average size of the village in Utena county is more than twice lower than the average in Lithuania. The largest villages are more typical for Western Lithuania, especially in Klaipeda region (Lithuania Minor). The average distance of villages from the administrative centres ranges from 15 to $21 \mathrm{~km}$, but some villages are far away about $50 \mathrm{~km}$. The nearest neighbourhood index, which is important for the infrastructure planning as well as the average distance, is $2.3 \mathrm{~km}$. Both last-mentioned indicators depend on the number and density of settlements, sometimes on configuration of the roads.

5. Density of villages, their sizes, in large part determines the influence of large, rapidly developing cities. It is estimated that the settlements of suburb zones are growing due to migrants moving from the cities as well as from periphery. The number of commuter population of this villages increasing due to better developed transport infrastructure, and etc.

The last conclusion should be the Lithuanian rural settlements transforms from the agrarian to urban society according the style of life. 